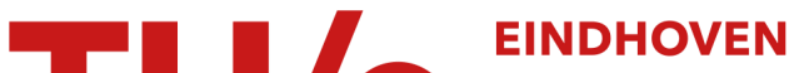 UNIVERSITY OF TECHNOLOGY
}

\section{A hydrogen-bonded porous solid derived from trimesic amide}

\section{Citation for published version (APA):}

Palmans, A. R. A., Vekemans, J. A. J. M., Kooijman, H., Spek, A. L., \& Meijer, E. W. (1997). A hydrogen-bonded porous solid derived from trimesic amide. Chemical Communications, ChemComm, 1997(22), 2247-2248. https://doi.org/10.1039/a705339h

DOI:

10.1039/a705339h

Document status and date:

Published: 01/01/1997

\section{Document Version:}

Publisher's PDF, also known as Version of Record (includes final page, issue and volume numbers)

\section{Please check the document version of this publication:}

- A submitted manuscript is the version of the article upon submission and before peer-review. There can be important differences between the submitted version and the official published version of record. People interested in the research are advised to contact the author for the final version of the publication, or visit the $\mathrm{DOI}$ to the publisher's website.

- The final author version and the galley proof are versions of the publication after peer review.

- The final published version features the final layout of the paper including the volume, issue and page numbers.

Link to publication

\section{General rights}

Copyright and moral rights for the publications made accessible in the public portal are retained by the authors and/or other copyright owners and it is a condition of accessing publications that users recognise and abide by the legal requirements associated with these rights.

- Users may download and print one copy of any publication from the public portal for the purpose of private study or research.

- You may not further distribute the material or use it for any profit-making activity or commercial gain

- You may freely distribute the URL identifying the publication in the public portal.

If the publication is distributed under the terms of Article 25fa of the Dutch Copyright Act, indicated by the "Taverne" license above, please follow below link for the End User Agreement:

www.tue.nl/taverne

Take down policy

If you believe that this document breaches copyright please contact us at:

openaccess@tue.nl

providing details and we will investigate your claim. 


\title{
Hydrogen-bonded porous solid derived from trimesic amide
}

\author{
Anja R. A. Palmans, ${ }^{a}$ Jef A. J. M. Vekemans, ${ }^{* a}$ Huub Kooijman, ${ }^{b}$ Anton L. Spek ${ }^{\dagger} \dagger$ and E. W. Meijer ${ }^{a}$ \\ a Laboratory of Organic Chemistry, University of Technology, PO Box 513, 5600MB Eindhoven, The Netherlands \\ ${ }^{b}$ Bijvoet Center for Biomolecular Research, Crystal and Structural Chemistry, University of Utrecht, Padualaan 8, $3584 \mathrm{CH}$ \\ Utrecht, The Netherlands
}

$N, N^{\prime}, N^{\prime \prime}$-Tris(3-pyridyl)trimesic amide, 1, forms a unique $P \overline{3}$ symmetrical crystal containing pores with a mean diameter of $8.26 \AA$.

Supramolecular assembly and crystal engineering are fruitful concepts to use in the design and development of structures with a desired shape. Recently these concepts evolved to be used in the construction of tubular superstructures ${ }^{1}$ and porous solids. ${ }^{2}$ Hydrogen bonding is one of the major tools which can be used to achieve the desired order. ${ }^{3}$

Here we report on the highly ordered infinite bilayer crystal structure of triamide $\mathbf{1}$; derived from trimesic acid (benzene1,3,5-triacarboxylic acid) and 3-pyridylamine. $\$$ In contrast to recently designed structures, ${ }^{4}$ our result was entirely serendipitous. Structure 1 served just as a model for comparison with intramolecularly hydrogen-bonded structure 2 , a precursor for extended core discotic liquid crystals of enhanced thermal stability. $^{5}$
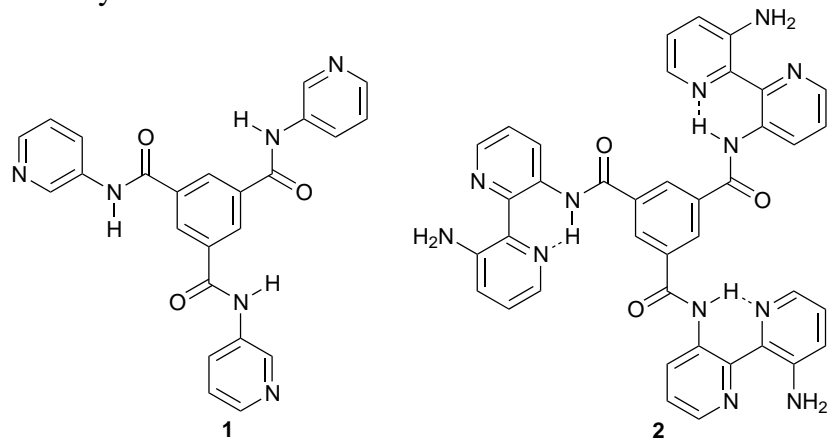

The transparent, hexagon-shaped crystals of $\mathbf{1}$, obtained upon crystallization from methanol, suggested hexagonal symmetry and prompted us to investigate a single crystal by X-ray diffraction. As indicated in Fig. 1 the asymmetric cell comprises only one third of a molecule while the unit cell is populated by two molecules. $\$$ Intermolecular hydrogen bonding between the pyridyl nitrogens and the amide NHs of adjacent molecules provides the basis for a macrocyclic organization in a rosettelike structure. A 30-membered macrocycle is formed with participation of six molecules and the 3-aminopyridyl units constitute the walls of a cavity with a mean diameter of $8.26 \AA$ (Fig. 2).

The $C_{3}$-symmetry of the molecule then allows for the creation of an infinite two-dimensional honeycomb grid with repeating units at $13.87 \AA$ in six directions and with a thickness of approximately $8.40 \AA$. According to Etter' $s^{6}$ graph set analysis the nitrogen hydrogen bond donors and acceptors are involved in a $R_{6}{ }^{6}(30)$ pattern. Closer inspection reveals the bilayer structure of an ensemble of molecules in one sheet (Fig. 3). The benzene units occupy alternating up and down positions. All the amide carbonyls point outwards, while the pyridyl units orientate their nitrogens inwards in the bilayer structure. This implies that although the crystal is achiral, the structure is a combination of trimesic units of $P$-helicity with units of $M$-helicity.
The infinite bilayer sheets themselves belong to a three dimensional super structure in which all the sheets are in fact repeating units placed exactly on top of each other. This results in the formation of a real porous structure with channels of

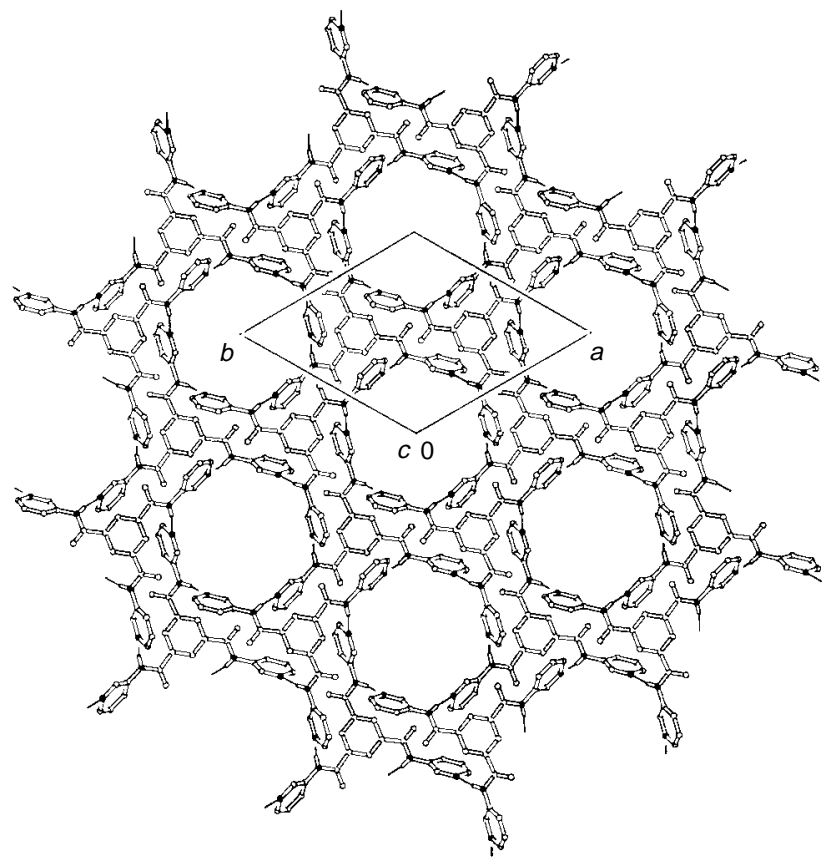

Fig. 1 Infinite rosette structure of 1

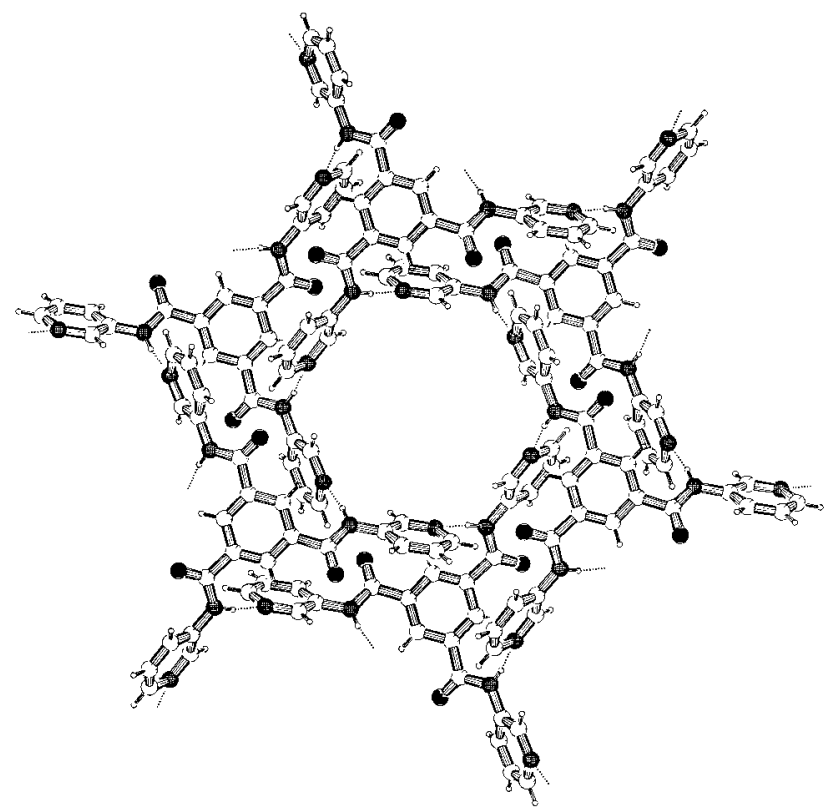

Fig. 2 Cavity in $\mathbf{1}$ as a result of six-fold intermolecular hydrogen bonding 


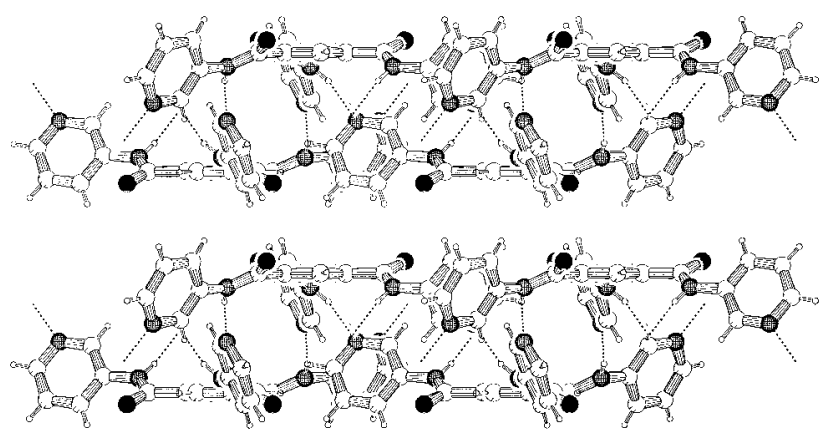

Fig. 3 Superimposed bilayer structure of 1 creating channels

nanometer scale diameter and millimeter scale length. The formation of this 3D structure may rest simply on optimal packing. Alternatively it is rationalized by cooperative $\mathrm{C}-\mathrm{H} \cdots \mathrm{O}$ interactions ${ }^{7}$ (total length $3.39 \AA$ ) between each amide oxygen and a pyridyl $\mathrm{C}-\mathrm{H}$ belonging to an adjacent bilayer.

Methanol is essential to guarantee the stability of the crystals, undoubtedly due to its role as a template and guest filling some of the void space in the interior of the channels, more specifically in the cavity surrounded by the six pyridyl units. The X-ray determination does not allow accurate localization of methanol in 1 but a molar ratio of $3: 1$ is estimated. According to the ${ }^{1} \mathrm{H}$ NMR spectrum in $\left[{ }^{2} \mathrm{H}_{6}\right] \mathrm{DMSO}$ the molar content of methanol ranges from 1.5 to 3.0 , depending on sample preparation. Elemental analysis of the crystals is irreproducible due to partial loss of methanol during analysis while analysis after removal of methanol at high temperature shows a deviation, presumably due to uptake of atmospheric (water) vapours. Upon heating between glass the crystals undergo, far below the melting point, a phase transition at $190{ }^{\circ} \mathrm{C}$, suggesting loss of methanol. In air or in solvents like toluene the crystals become opaque and disintegrate. In pentane, by contrast, the crystals are stable.

To provide evidence for the accessibility of the channels for external molecules, a methanol- $\mathrm{CD}_{3} \mathrm{OD}$ exchange experiment was conductedII and the ${ }^{1} \mathrm{H}$ NMR spectrum in $\left[{ }^{2} \mathrm{H}_{6}\right] \mathrm{DMSO}$ unambiguously demonstrates the complete disappearance of non-deuteriated methanol from the crystals. Analogous experiments have been conducted in other trimesic acid derivatives and in other tectonic molecules. ${ }^{8}$ The calculated density of 1

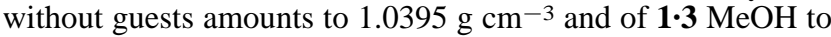
$1.267 \mathrm{~g} \mathrm{~cm}^{-3}$. This relatively low density contrasts with the higher density of many trimesic derivatives including the parent acid $\left(1.449 \mathrm{~g} \mathrm{~cm}^{-3}\right) .^{9}$

The presence of $C_{3}$-symmetry tends to induce void space in crystals, which Nature may compensate for by producing concatenated or interpenetrated structures or by incorporation of appropriate guest molecules. To our surprise, up to now no $\mathrm{X}$-ray data are available on symmetrical secondary trimesic amides. In trimesic acid three-fold interpenetration of twodimensional layers composed of three parallel molecules is observed, ${ }^{9}$ unless guests like pyrene and ethanol are built in. ${ }^{10}$ A pattern such as the one found in compound $\mathbf{1}$ is, to the best of our knowledge, unprecedented. It seems that in this particular molecule an acceptable compromise is found between void space, concatenation of molecules and inclusion of guests. The formation of a bilayer structure in compound $\mathbf{1}$ is reminiscent of the Piedfort units observed in other $C_{3}$-symmetric systems like 2,4,6-tris[4-(2-phenylpropan-2-yl)phenoxy]-1,3,5-triazine, ${ }^{11}$ in which two $\pi$-stacked molecules are mutually rotating by $60^{\circ}$ to resemble a spatially filled hexagonal system.

This work was supported in part by the Netherlands Foundation of Chemical Research (SON) with financial aid from the Netherlands Organization for Scientific Research (NWO). DSM Research is gratefully acknowledged for an unrestricted grant.

\section{Footnotes and References}

* E-mail: tgtojv@chem.tue.nl

$\dagger$ Correspondence address for crystallographic data.

$\ddagger$ Crystal structure data for 1: $\mathrm{C}_{24} \mathrm{H}_{18} \mathrm{~N}_{6} \mathrm{O}_{3}, M_{\mathrm{r}}=438.45$, colourless, block-shaped crystal $(0.3 \times 0.5 \times 0.5 \mathrm{~mm})$, trigonal, space group $P \overline{3}$ (no. 147) with $a=13.8762(10), c=8.4005(5) \AA, V=1400.80(17) \AA^{3}, Z=2$, $D_{c}=1.039 \mathrm{~g} \mathrm{~cm}^{-3}, F(000)=456, \mu(\mathrm{Mo}-\mathrm{K} \alpha)=0.7 \mathrm{~cm}^{-1}, 4819$ reflections measured, 2135 independent, $R_{\text {int }}=0.0288,1.7^{\circ}<\theta<27.5^{\circ}$, $\omega$ scan, $T=150 \mathrm{~K}$, Mo-K $\alpha$ radiation, graphite monochromator, $\lambda=0.71073 \AA$ on an Enraf-Nonius CAD4 Turbo diffractometer on rotating mode. Data were corrected for Lp effects and for a linear instability of $1 \%$ of the reference reflections, but not for absorption. The structure was solved by automated direct methods (SHELXS96). Refinement on $F^{2}$ was carried out by full-matrix least-squares techniques (SHELXL96); no observance criterion was applied during refinement. Electron density in a disordered solvent area (the unit cell contains a channel parallel to the $c$-axis, through the origin, with a volume of $450 \AA^{3}$ and containing 111 electrons per $c$-translation period, suggesting the presence of approximately six molecules of methanol) was taken into account in the refinement via PLATON/ SQUEEZE. Where relevant, data cited above are given without disordered solvent contribution. Positional parameters for hydrogen atoms were included in the refinement; initial values were obtained from a difference Fourier map. Refinement converged at a final $w R 2$ value of 0.0973 $R 1=0.0376$ [for 1727 reflections with $F_{\mathrm{o}}>4 \sigma\left(F_{\mathrm{o}}\right)$ ], $S=1.071$, for 118 parameters. A final difference Fourier showed no residual density outside -0.20 and $0.24 \mathrm{e}^{-3}$. CCDC $182 / 632$.

$\S$ Synthesis of 1: Standard reaction of trimesic chloride $(0.90 \mathrm{~g}, 3.39 \mathrm{mmol})$ with 3-pyridylamine $(1.00 \mathrm{~g}, 10.6 \mathrm{mmol})$ in THF $(20 \mathrm{ml})$ in the presence of triethylamine $(1.6 \mathrm{ml}, 1.13 \mathrm{~g}, 11.2 \mathrm{mmol})$ afforded a precipitate which after washing with water and diethyl ether and drying in vacuo gave $1(1.18 \mathrm{~g}$, $79 \%)$ as a white solid. Recrystallization from methanol $(200 \mathrm{ml})$ afforded large, transparent hexagonal crystals, mp 287-289 ${ }^{\circ} \mathrm{C} ; \delta_{\mathrm{H}}\left(\left[{ }^{2} \mathrm{H}_{6}\right] \mathrm{DMSO}\right)$ 10.87 (s, NH), 9.01 (d, H-2'), 8.82 (s, H-2, 4, 6), 8.39 (dd, H-6'), 8.26 (ddd, $\left.\mathrm{H}-4^{\prime}\right), 7.47$ (dd, $\left.\mathrm{H}^{-5} 5^{\prime}\right), 4.15(\mathrm{~s}, \mathrm{OH}), 3.18\left(\mathrm{~s}, \mathrm{CH}_{3}\right) ; \mathrm{m} / \mathrm{z}(\mathrm{ES})(\mathrm{MeOH}+$ $\mathrm{HCO}_{2} \mathrm{H}$ ) Calc. for $\mathrm{C}_{24} \mathrm{H}_{18} \mathrm{~N}_{6} \mathrm{O}_{3} 438.142$. Found: $439.1(\mathrm{M}+\mathrm{H})^{+}$and 219.9 $(\mathrm{M}+2 \mathrm{H})^{2+}$. Analysis (after exhaustive removal of methanol at $150{ }^{\circ} \mathrm{C}$ ) Calc. C, 65.75; H, 4.14; N, 19.17. Found: C, 64.80; H, 4.17; N, $18.78 \%$. II Crystals of $\mathbf{1} \cdot(\mathrm{MeOH})_{x}$ were unloaded from exterior $\mathrm{MeOH}$ by repetitive immersion in pentane. Crystals were kept in $\mathrm{CD}_{3} \mathrm{OD}$ for four days. The crystals remained intact and were then filtered and washed with pentane. The ${ }^{1} \mathrm{H}$ NMR spectrum in $\left[{ }^{2} \mathrm{H}_{6}\right] \mathrm{DMSO}$ indicated the complete replacement of $\mathrm{MeOH}$ by $\mathrm{CD}_{3} \mathrm{OD}$.

1 E. Weber, R. Pollex and M. Czugler, J. Org. Chem., 1992, 57, 4068; D. Venkataraman, S. Lee, J. Zhang and J. S. Moore, Nature, 1994, 371 591; M. R. Ghadiri, Adv. Mater., 1995, 7, 675.

2 G. B. Gardner, D. Venkataraman, J. S. Moore and S. Lee, Nature, 1995, 374, 792; P. Brunet, M. Simard and J. D. Wuest, J. Am. Chem. Soc. 1997, 119, 2737.

3 V. A. Russell and M. D. Ward, Chem. Mater., 1996, 8, 1654; E. Fan, C. Vicent, S. J. Geib and A. D. Hamilton, Chem. Mater., 1994, 6, 1113 .

4 N. Khazanovich, J. R. Granja, D. E. McCree, R. E. Milligan and M. R. Ghadiri, J. Am. Chem. Soc., 1994, 116, 6011; M. D. Ward, Nature, 1995, 374, 764; R. E. Melendez, C. V. Krishnamohan Sharma, M. J. Zarawotko, C. Bauer and R. D. Rogers, Angew. Chem., Int. Ed. Engl., 1996, 35, 2213; M. Mascal, N. M. Hext, R. Warmuth, M. H. Moore and J. P. Turkenburg, Angew. Chem., Int. Ed. Engl., 1996 35, 2204; R. Bishop, Chem. Soc. Rev., 1996, 311.

5 A. R. A. Palmans, J. A. J. M. Vekemans, H. Fischer, R. A. Hikmet and E. W. Meijer, Chem. Eur. J., 1997, 3, 300.

6 M. C. Etter, Acc. Chem. Res., 1990, 23, 120.

7 Z. Berkovich-Yellin and L. Leiserowitz, Acta Crystallogr., Sect. B, 1984, 40, 1596; G. R. Desiraju, Acc. Chem. Res., 1996, 29, 441.

8 (a) A. Mahdyarfar and K. D. M. Harris, J. Chem. Soc., Chem. Commun., 1993, 51; (b) X. Wang, M. Simard and J. D. Wuest, J. Am. Chem. Soc., 1994, 116, 12119; (c) O. M. Yaghi, G. Li and H. Li, Nature, 1995, 378, 704.

9 D. J. Duchamp and R. E. Marsh, Acta Crystallogr., Sect. B, 1969, 25, 5.

10 S. V. Kolotuchin, E. E. Fenlon, S. R. Wilson, C. J. Loweth and S. C. Zimmerman, Angew. Chem., Int. Ed. Engl., 1995, 34, 2654

11 A. S. Jessiman, D. D. MacNicol, P. R. Mallinson and I. Vallance, J. Chem. Soc., Chem. Commun., 1990, 1619.

Received in Bath, UK, 23rd July 1997; 7/05339H 